\title{
Intergenerational Perceptions of Coercive and Legitimate Power
}

\author{
Elisa Tjondro ${ }^{1}$, Joscelind Setiabudi ${ }^{2}$, Alexandro Christian Joyo ${ }^{3}$ \\ 1,2,3 Universitas Kristen Petra, Indonesia \\ 1elisatjondro@petra.ac.id, 2joscelind13@gmail.com, ${ }^{3}$ alexandro.christian@yahoo.com
}

\begin{abstract}
This is the first research to examine the perception of the coercive and legitimate power of tax authority between three generations, namely Millennials, $\mathrm{X}$ and Baby Boomers. Method of data collection used a survey with a total sample of 120 taxpayers from two types of business, retail/production and services/professions in five major cities in Indonesia (Jakarta, Surabaya, Bandung, Semarang, and Denpasar). This survey was held in 2018. This study used a quota sampling technique with Custom Factorial ANOVA as a statistical tool. We found Millennials and $\mathrm{X}$ have a perception that Indonesia tax authority implemented coercive and legitimate power in balance conditions. However, different perceptions found in Baby Boomers that thought of tax authority had been implemented coercive power with more severe punishment. The study also found differences in perceptions of vertical equity, horizontal equity, and exchange equity between the generations.
\end{abstract}

Keywords: intergenerational, coercive power, legitimate power, vertical equity, horizontal equity, exchange equity.

\section{Persepsi Kekuatan Koersif dan Kekuatan Legitimasi Antargenerasi}

\begin{abstract}
Abstrak
Penelitian ini adalah penelitian pertama yang menguji persepsi kekuatan koersif dan kekuatan legitimasi pada otoritas pajak antara tiga generasi, yaitu Millennials, X dan Baby Boomers. Peristiwa yang terjadi selama periode tertentu mempengaruhi persepsi antar generasi. Metode pengumpulan data menggunakan survei dengan total sampel 120 wajib pajak dari dua jenis bisnis, ritel/produksi dan jasa/profesi di lima kota besar Indonesia (Jakarta, Surabaya, Bandung, Semarang, dan Denpasar). Survei diadakan pada tahun 2018. Penelitian menggunakan teknik kuota sampling dengan Custom Factorial ANOVA sebagai alat statistik. Hasil tes menemukan Milenial dan X menilai bahwa otoritas pajak menerapkan kekuatan koersif dan kekuatan legitimasi dalam kondisi seimbang. Namun, persepsi berbeda ditemukan pada Baby Boomers yang berpikir otoritas pajak telah menerapkan kekuatan koersif dengan hukuman yang lebih berat kepada wajib pajak. Studi ini juga menemukan adanya perbedaan persepsi terkait ekuitas vertikal, ekuitas horisontal, dan pertukaran ekuitas antar generasi.
\end{abstract}

Kata kunci: antar generasi, kekuatan koersif, kekuatan legitimasi, ekuitas vertikal, ekuitas horizontal, pertukaran ekuitas.

\section{INTRODUCTION}

Every generation that is born must have their enthusiasm. Mannheim became the first to examine the development of generation values based on sociological writings about generations in the 1920s and 1930s. In his research revealed that the individual social awareness and perspective, from youth to reach maturity, influenced by the crucial events that have passed. Since that time, many researchers have begun to examine differences in values between generations by using the generation theory of Howe and Strauss and generational cohort theory (Gentry, Griggs, Deal, Mondore, \& Cox, 2011; Parry \& Urwin, 2011; Jackson, Stoel, \& Brantley, 2011; Brosdahl \& Carpenter, 2011; Obal \& Kunz, 2013). The grouping of these generations is influenced by historical events and cultural phenomena 
that occur in the phase of their lives (Noble \& Schewe, 2003; Jackson et al., 2011), and these events and phenomena cause the formation of collective memories that have an impact on their lives (Dencker, Joshi, \& Martocchio, 2008; Obal \& Kunz, 2013). Therefore historical, social, and cultural effects along with other factors will influence the formation of behavior, values, and personality possessed by a person (Caspi \& Roberts, 2001; Jurney, Rupert, \& Wartick, 2017). In our study, the generation group was divided into three groups (Jurney et al., 2017), namely Millennials (born in 1980-2000), X (1965-1979), and Baby Boomers (1945-1964).

Every group has a unique characteristic that shapes perception. The millennial generation is characterized by technological advances and increasing global and economic interactions that are developing very rapidly (Jurney et al., 2017). Millennials also had attitudes that were more accepting of noncompliance than Baby Boomers and X (Jurney et al., 2017). Furthermore, Lyons (2003) reveals the characteristics of the Millennial generation, namely their communication patterns that are very open compared to previous generations. Millennials oriented to success, creativity, freedom of information that is a priority (Bencsik \& Machova, 2016). Generation X is one of the most highly educated generations (Jackson et al., 2011). Generation X is a generation born in the early days of technological and information developments such as the emergence of PCs (personal computers), video games, cable TV, and the internet. Generation X has little tolerance for bureaucracy and rules, especially concerning time and attendance (Gursoy, Maier, \& Chi, 2008). According to Jurkiewicz (2000), generation $X$ is able to adapt, be able to accept changes well and is called a strong generation, has independent and loyal character, highly prioritizes image, fame and money, type of hard worker, and calculates the contribution that the company has made to the results of his work. The Baby Boomer generation was born in the early days of World War II and Indonesia's Independence Day in 1945 and a period where marriage rates were very high resulting in high birth rates. According to (Bencsik \& Machova, 2016), Baby Boomers are hard workers, profoundly respecting tradition and hierarchy, different from Millennials who tend not to respect hierarchy and tradition.

Ramli et al. (2018) suggested that perception may be influenced by two essential steps of elements for response and elements of sensory experience. These beliefs and perceptions are influenced by prior experience, judgments, knowledge and the education and information efforts by policymakers (Kneeshaw, Vaske, Bright, \& Absher, 2004). From several previous studies, we concluded the past period when someone grew and developed, involvement in technology, and responding to policymakers are the factors that influence the perception of taxpayers in the present. This causes different perspectives or perceptions of things between generations, one of which is the perception of the figures of the authority.

We argue that each generation has a different view regarding the use of coercive and legitimate power in tax collection. Considering the characteristics of each generation, Baby Boomers have respect for authority figures (Bencsik \& Machova, 2016). The word respect for authority figures can often cause fear to make mistakes or break the law. Therefore, according to its characteristics, the Baby Boomer generation is more able to accept the 
concept of coercive power from authority figures. Unlike the Baby Boomer, the Millennial grew up in the era of rapidly developing technology. Lyons (2003) reveals that Millennials have communication patterns that are more open than previous generations. This shows that communication is vital for this generation. Thus, according to the characteristics of the Millennial, they tend to be able to accept the legitimate power of authority figures. This is because legitimate power is closely related to the service climate, which means more attention to the provision of services (Hofmann, Hartl, Gangl, Hartner-Tiefenthaler, \& Kirchler, 2017). Service delivery is an effective way of communicating information, policies and work programs of the tax authorities in more detail and clarity. The character of generation $\mathrm{X}$ has little tolerance for bureaucracy and rules and fiercely independent compared to the other groups (Gursoy et al., 2008). Generation X expects coercive and legitimate power of authority figures to run in a balanced and concurrent manner. For them, the exercise of power will be more effective if through strict sanctions accompanied by excellent service.

The contribution of this research is the first study that examines the perception of coercive and legitimate power between generations in the context of the tax authority. We suspect that certain generations are more supportive of legitimate power than coercive power in tax collection. Therefore it cannot be applied arbitrarily. As a result of excessive coercive power, implementation will lead to rejection from specific generations, increasingly massive tax evasion actions, and tax collection becomes ineffective. Second, this study aims to prove that generation $X$ expects the application of coercive and legitimate power in a balanced manner by the DGT. There are several underlying reasons. First, generation $\mathrm{X}$ prefer to blend traditional method with technological tools to enhance their development opportunities because they enjoy the personalization and convenience offered by technologies (Neal \& Wellins, 2018). Second, generation $X$ also refer to as the powerful combination of digital and conventional leadership skill, who has a strong lead character's view as in the perspective of the Baby Boomers but has the ability to carry out tasks digitally like Millennials (Neal \& Wellins, 2018).

We also examined the perception of tax fairness through three variables of horizontal equity, vertical equity, and exchange equity that were tested in the research of Jurney et al. (2017) and Efebera, Hayes, Hunton, \& O'Neil (2015). Previous researchers have found that perceptions regarding tax systems that are unfair will have an impact on taxpayers' disobedience to the tax regulations. Research conducted by Andreoni, Erard, Feinstein, Andreoni, \& Feinstein (1998) found that when taxpayers consider themselves victims of fiscal injustice, it will increase the amount of tax evasion. Similar to the study, Siahaan (2005) found that perceptions regarding tax systems that were unfair would increase the tendency of taxpayers to carry out tax avoidance.

In research conducted by Gangl, Hofmann, \& Kirchler (2015) power is defined as the capacity of an organization or person to influence the behavior of others. In general, there are two possible reasons why people obey power holders. First, they want to avoid penalties or sanctions they will pay if they violate the rules (Ariel, 2012). Second, there is a division of roles between power holders (tax authority) and subordinates (taxpayers) that 
agreed by both parties. In this case, people consider the authority to be legitimate, and therefore that power is based on the joint decision (Kastlunger, Lozza, Kirchler, \& Schabmann, 2013). There are two categories of power, namely "hard" power and "soft" power. (Gangl et al., 2015) then used the term coercive power to define "hard" power and legitimate power to define "soft" power.

Coercive power is the power of the tax authorities to force taxpayers to pay taxes because they are afraid of tax audits and strict sanctions (Kastlunger et al., 2013). Whereas in Gangl et al. (2015), coercive power is defined as the ability to detect and impose sanctions against unlawful behavior. In other words, coercive power is the power that directs someone against their will (Kirchler, Hoelzl, \& Wahl, 2008). Coercive power or "hard" power is realized through negative and positive approaches such as through the imposition of sanctions and awarding (Raven, Schwarzwald, \& Koslowsky, 1998). Negative approaches, such as the imposition of fines and imprisonment, are common steps and are proved to be effective to influence one's behavior, generally used by the tax authority. While a positive approach, in the form of an appreciation for an honest Taxpayer, is something that is not commonly used by tax authorities to influence a person's behavior (Becker, 1968). Being confronted with coercive power, respondents immediately feel aversive arousal. They feel anger, experience reactance, and show behavioral intentions to re-establish their freedom (Sittenthaler, Steindl, \& Jonas, 2015). Thus, people who deal with coercive power may immediately feel their emotions boiling over. They are physiologically activated to "fight" for their freedom (Sittenthaler et al., 2015).

Legitimate power is not based on pressure and strength but is based on legitimacy, the provision of relevant information, authority knowledge and skills, and the capacity of the tax authorities to make taxpayers identify specific policies with the authorized tax authorities (Raven et al., 1998). In Gangl, Hofmann, Pollai, \& Kirchler (2012) legitimate power is defined as the legitimacy, knowledge, and ability of tax authorities that leads to the efficacy of tax authorities in carrying out their work, and encourages the confidence of taxpayers in the presence of tax authorities. Based on these studies, Kastlunger et al. (2013) defined legitimate power as the efficacy of an authorized tax authority (because of its expertise and ability) to ensure cooperation with taxpayers. Legitimate power is considered high if tax crimes can be detected reasonably and the tax authorities can handle them efficiently because of their competencies. According to (Gangl et al., 2015), legitimate power is based on the fact that the authorized tax authorities mobilize legitimate forces to convince taxpayers to work together using the legitimacy, charisma, expertise, and information DGT have. Different from coercive power, legitimate restrictions may first be followed by a delay followed by physiological arousal (Sittenthaler et al., 2015). People in the legitimate condition seem to need some more time to recognize the unobvious authority restriction. This could mean that people first have to reflect upon and argue against the restriction before getting into the same arousal state as people of the coercive restriction (Sittenthaler et al., 2015).

We defined authorities as processes to organize the cooperation in a community by an assigned social position that allows to create and maintain environments and thereby 
influence the behavior of individuals (Andringa, van den Bosch, \& Vlaskamp, 2013). In Indonesia, the tax power is in the hands of authority figures, namely the Directorate General of Tax (DGT). However, the DGT has power under the Ministry of Finance of the Republic of Indonesia to process tax disputes in the case of the objection process (Table 2). DGT also has the authority to carry out tax collection activities through cooperation with police agencies (Table 1). One of these tax collection activities is to carry out a hostage-taking against taxpayers. This action was later known as gijzeling. Gijzeling is a temporary restraint on the freedom of the taxpayer by placing him in a particular place, not imprisoned. Hostage or gijzeling activity itself is one of a series of tax collection actions carried out by DGT so that the taxpayers repay tax debt.

Table 1. Government policies on the power of DGT of Indonesia

\begin{tabular}{|c|c|c|}
\hline $\begin{array}{l}\text { DGT has the power to } \\
\text { decide tax disputes in the } \\
\text { case of the objection } \\
\text { process }\end{array}$ & $\begin{array}{l}\text { Taxpayers can submit objections } \\
\text { only to the Director General of } \\
\text { Taxes (DGT) on the result of the } \\
\text { tax audit. }\end{array}$ & $\begin{array}{l}\text { Article } 25 \text { number } 1 \text { Act of } \\
\text { The Republic of Indonesia } \\
\text { number } 28 \text { the year } 2007 \\
\text { concerning General } \\
\text { Provision and Tax } \\
\text { Procedures }\end{array}$ \\
\hline $\begin{array}{l}\text { DGT has the power to } \\
\text { issue permits for tax } \\
\text { consultants }\end{array}$ & $\begin{array}{l}\text { To be able to practice as a Tax } \\
\text { Consultant, a Tax Consultant } \\
\text { who has fulfilled the } \\
\text { requirements referred to in } \\
\text { Article } 2 \text {, must have a Practice } \\
\text { Permit issued by the Director } \\
\text { General of Taxes or a designated } \\
\text { official. }\end{array}$ & $\begin{array}{l}\text { Regulation of the Minister of } \\
\text { Finance No } 111 \text { / PMK.03 / } \\
2014 \text { article } 3 \text { number } 1 \text { about } \\
\text { Tax Consultant }\end{array}$ \\
\hline $\begin{array}{l}\text { DGT work with the Police } \\
\text { in terms of law enforcement } \\
\text { in the field of taxation }\end{array}$ & $\begin{array}{l}\text { The Parties must provide } \\
\text { operational support and guidance } \\
\text { in the implementation of law } \\
\text { enforcement as requested based } \\
\text { on applicable laws and } \\
\text { regulations. }\end{array}$ & $\begin{array}{l}\text { Memorandum of } \\
\text { Understanding between the } \\
\text { Ministry of Finance and the } \\
\text { Indonesian National Police } \\
\text { MOU-1 / MK.09 / } 2012 \\
\text { Article } 6 \text { number } 1 \\
\text { concerning law enforcement } \\
\text { in the field of taxation }\end{array}$ \\
\hline
\end{tabular}

Sources: Republic of Indonesia, (2007); Republic of Indonesia, (2014); Republic of Indonesia, (2012)

Indonesia government has already submitted the draft bill of KUP Law to parliament as part of changes in DGTs organizational structure (Setiaji, 2018), which reveals the government plans to separate the DGT from the Ministry of Finance. Later, the DGT will become an autonomous body directly under the president even though he still coordinates with the Ministry of Finance. Darussalam, Kristiaji, \& Klise (2013) divided two variations of the institutional framework, namely: the tax authority under the institutional structure of the finance ministry and the tax authority which has broader autonomy. The institutional framework changes at DGT organization will result in broader autonomy and the enormous power of DGT.

Coercive power is effective when sufficient resources are needed to protect fraud from regulation and the application of supported agreements (Becker, 1968; Mulder, Verboon, \& Cremer, 2009). In conditions where power is not found and is not eradicated, 
coercive power is perceived as weak, because the motives are enforced, the desires will decrease (Hofmann et al., 2017). In conditions such as Indonesia with a ratio of tax officers and residents is 1:7700 (Misbakhun, 2018) then the application of coercive force is not effective.

Considering the characteristics of each generation, we argue that each generation has a different view regarding the use of coercive and legitimate power in tax collection. Millennials who live in a period of increasing global and economic interactions (Jurney et al., 2017), have more attitudes to accept noncompliance (Jurney et al., 2017), has a more open communication pattern (Lyons, 2003), freedom of information is a priority (Bencsik \& Machova, 2016), expect to be heard (Hartman \& Mccambridge, 2011). We argue that Millennials tend to prefer the application of legitimate power in tax collection. Millennials tend to support the application of the concept of legitimate power by the tax authorities because legitimate power is closely related to the service climate, which means more attention to the provision of services (Hofmann et al., 2017). Millennials want cooperation between DGT and taxpayers involves legitimacy, charisma, expertise, and giving information. Tax collection through coercive power only will cause Millennials to behave noncompliance. Baby Boomers have respect for authority figures (Bencsik \& Machova, 2016). The word respect for authority figures can often cause fear to make mistakes or break the law. Therefore, according to its characteristics, the Baby Boomer generation more supportive of the implementation of the coercive power concept by the tax authorities. The characteristic of generation $\mathrm{X}$ that have little tolerance for bureaucracy and rules, respect to time and attendance, and fiercely independent (Gursoy et al., 2008), moreover, we conclude generation $\mathrm{X}$ is more expecting the implementation of the coercive power concept and the legitimate power of the tax authorities to run in a balanced and concurrent manner. For generation $\mathrm{X}$, the exercise of power will be more effective if through strict sanctions accompanied by excellent service. Therefore relating to the above explanation, the hypothesis are proposed $\mathrm{H} 1$ : there are differences in perceptions between generations regarding coercive power; and $\mathrm{H} 2$ : there are differences in perception between generations related to legitimate power.

The principle of tax justice can be seen from three perspectives, namely vertical equity, horizontal equity, and exchange equity. Vertical equity refers to the perception of taxpayers' equity regarding their tax burden with other taxpayers who have greater income (Jurney et al., 2017). Vertical equity arises when low-income taxpayers feel that the tax burden they pay is greater than high-income taxpayers (Efebera et al., 2015). This concept underlies progressive income tax implementation. Concerning the influence of different generations on vertical equity, previous research found that Millenials have a low preference on vertical equity than the other generations (Jurney et al., 2017). The reason is that Millennials have characteristics in which they are more focused on self-interest (Bencsik \& Machova, 2016). Moreover, this generation considers that imposing progressive tax tariffs will harm them. The Baby Boomers in retirement, where the income tends to fall and taxes are paid less, tend to rely on passive income such as interest on deposits, income on land and building rent, and land/building sales (Tjondro, Santosa, \& Prayitno, 2019). This 
makes the Baby Boomer support the imposition of a progressive tax rate, so that the higher the taxpayer's economic capacity, the higher the tax burden paid. Generation X is in its productive period where this generation's income is the largest compared to other generations, so we suspect that generation $\mathrm{X}$ tends not to support vertical equity. Hypothesis three of this study is H3: there are differences in perceptions between generations regarding vertical equity in the tax system.

Horizontal equity refers to the perception of taxpayers' equity regarding their tax burden about other taxpayers who have the same income. Horizontal inequity arises when taxpayers perceive that they share on the tax burden disproportionately larger than other taxpayers with relatively equal income (Efebera et al., 2015). The characteristics of Millennials that are identical to technological advances, global interaction (Jurney et al., 2017), oriented to success and creativity (Bencsik \& Machova, 2016) make Millennials tend to enjoy several types of business or profession. Therefore, we argue that Millennials are more supportive on horizontal equity concept than other generations. Therefore relating to the above explanation, hypothesis four is proposed $\mathrm{H} 4$ : there are differences in perceptions between generations regarding horizontal equity in the tax system.

Exchange equity refers to the perceived fairness of taxpayers from the exchange relationship between taxpayers and tax authorities, or the benefits felt by taxpayers on each nominal tax paid (Jurney et al., 2017). Exchange equity refers to the perceived fairness of the trade or the benefit received for nominal paid (Efebera et al., 2015). Concerning the characteristic differences, Millennials and $\mathrm{X}$ tend to support the application of exchange equity since communication and interaction are their priority (Lyons, 2003; Bencsik \& Machova, 2016). Therefore, Millennials and X need to be constantly convinced for the use of tax they already paid. Hypothesis five is $\mathrm{H} 5$ : there are differences in perceptions between generations regarding exchange equity in the tax system.

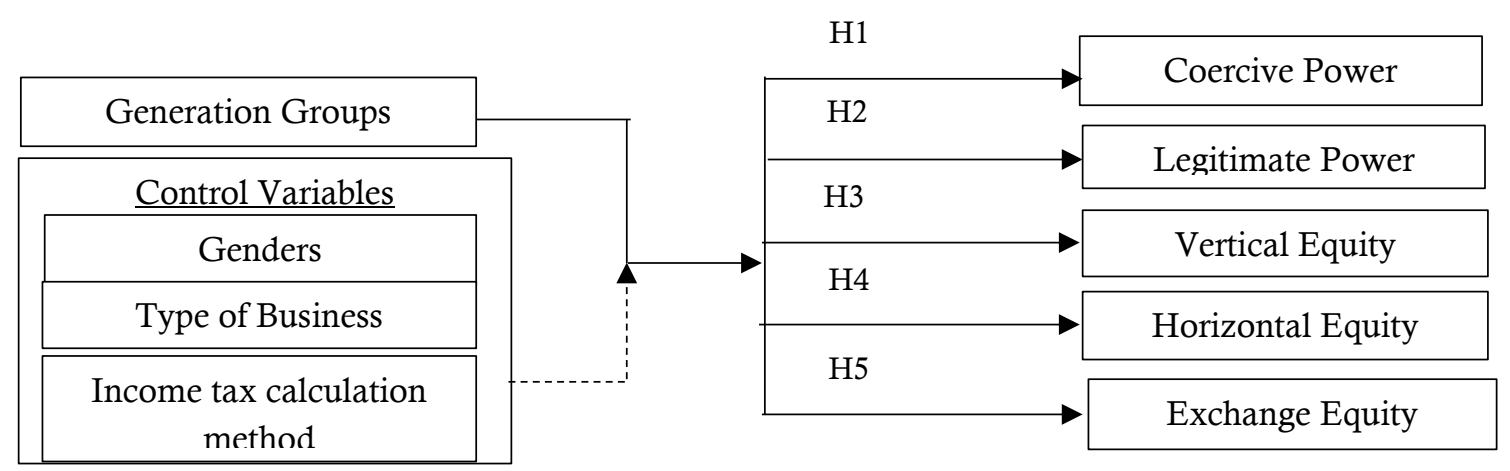

Figure 1: Conceptual Framework

\section{METHOD}

The subject of research in this study is all individual taxpayers who have a business related to retail/production or services/profession occupations, which are domiciled in the cities of Jakarta, Bandung, Semarang, Surabaya, and Denpasar. The individual taxpayers who own business are selected since they are responsible for their tax payment and tax reporting (selfassessment system). We use a survey method for data collection. In August 2018, we started 
sending the questionnaire online to random taxpayers in communities of parents of our students. We received total of 175 questionnaires for all groups that are responded, and only 120 meet the criteria, so we obtained observations of 40 respondents for each group. Determination of samples using the non-probability sampling which is the quota sampling method. We choose respondents based on the following criteria: (1) the number of respondents between generations is equal, (2) the number of male and female respondents is equal, (3) the number of respondents who own a business in retail/production or services/profession occupation are equal, (4) respondents represent the cities of Jakarta, Bandung, Semarang, Surabaya, and Denpasar, (5) respondents represent "recording" method and "bookkeeping" method, which in Indonesia tax system determined by the gross income of business, (6) understanding the prevailing tax system in Indonesia, which is seen from filling in the Annual Tax Return for the last 3-5 years, (7) the number of respondents who fill out their tax return with and without tax consultants are the same.

We measure coercive power for two indicators, tax audit and application of sanctions, and the measurement of legitimate power of tax officers for legitimacy, charisma, expertise, and providing information for taxpayers. We modified the questionnaire from prior research, which is (Hartl, Hofmann, Gangl, Hartner-Tiefenthaler, \& Kirchler, 2015). The questions concerning vertical equity are modified from the research of (Efebera et al., 2015) to measure perception about the progressive rate. The question concerning horizontal equity and exchange equity is adapted and combined from the previous research, which is (Jurney et al., 2017) and (Efebera et al., 2015) to measure horizontally equitable and benefits received for the payment of tax. The questionnaire is in the appendix. The measurement scale used for coercive power, legitimate power, vertical equity, horizontal equity, and exchange equity is a seven-point Likert scale, from "strongly disagree" up to "strongly agree" opinions. Besides, this study uses control variables to avoid bias on testing generation effect to the dependent variables. This study uses three control variables: gender (male or female), business type (retail/production or services/profession), and method of calculating income tax (gross income $<4.8$ billion or gross income $\geq 4.8$ Billion) with dummy variables.

This study uses Custom Factorial ANOVA to determine differences in perceptions between three group of generations. This study uses ANOVA because ANOVA is suitable for testing differences between groups and the control variables in this study use dummy variables. To test the validity of each question, we carried out a factor analysis using Pearson Correlation. For each statement, items show Pearson correlation value ranging from 0.618 to 0.921 , means that the significance value of each item $\geq 0.5$, so it can be determined that all questions are valid. The value of the Cronbach's alpha is acceptable when each value is the same or more than 0.6 and 0.7 (Kock \& Lynn, 2012). The value of each variable which ranging from 0.627 to 0.952 has met the standard which means they are reliable.

\section{FINDING AND DISCUSSION}

This study uses a questionnaire instrument that has been distributed in 2018, with the object of research of individual taxpayers who have businesses in the retail and production fields as well as free work spread in the cities of Jakarta, Bandung, Semarang, Surabaya, and 
Denpasar. The distribution of questionnaires was carried out online in the form of Google Form. The entire questionnaire responded in this research was 175 questionnaires. Of the total questionnaires that have been responded, only 120 questionnaires can be analyzed and meet the criteria. Questionnaires that did not meet the criteria of the study included respondents with business locations outside the city that those specified and respondents did not fill out the tax return within a minimum period of 3-5 years.

Table 2. Demographic Summary of Respondents $(n=120)$

\begin{tabular}{|c|c|c|c|c|c|}
\hline & & $\begin{array}{c}\text { Total } \\
\text { Sample } \\
(n= \\
120)\end{array}$ & $\begin{array}{l}\text { Millennials } \\
(n=40)\end{array}$ & $\begin{array}{l}\text { Generation } \\
\mathrm{X}(n=40)\end{array}$ & $\begin{array}{c}\text { Baby } \\
\text { Boomers } \\
(n=40)\end{array}$ \\
\hline \multirow{2}{*}{ Gender } & Male & $50,8 \%$ & $55,0 \%$ & $60,0 \%$ & $37,5 \%$ \\
\hline & Female & $49,2 \%$ & $45,0 \%$ & $40,0 \%$ & $62,5 \%$ \\
\hline \multirow{2}{*}{$\begin{array}{l}\text { Business } \\
\text { Type }\end{array}$} & Retails/Productions & $54,2 \%$ & $50,0 \%$ & $52,5 \%$ & $60,0 \%$ \\
\hline & Services/Profession & $45,8 \%$ & $50,0 \%$ & $47,5 \%$ & $40,0 \%$ \\
\hline \multirow{5}{*}{$\begin{array}{l}\text { Business } \\
\text { Location } \\
\text { (City) }\end{array}$} & Jakarta & $19,2 \%$ & $7,5 \%$ & $25,0 \%$ & $25,0 \%$ \\
\hline & Bandung & $4,2 \%$ & $0,0 \%$ & $10,0 \%$ & $2,5 \%$ \\
\hline & Semarang & $10,0 \%$ & $2,5 \%$ & $25,0 \%$ & $2,5 \%$ \\
\hline & Surabaya & $50,0 \%$ & $77,5 \%$ & $30,0 \%$ & $42,5 \%$ \\
\hline & Denpasar & $16,7 \%$ & $12,5 \%$ & $10,0 \%$ & $27,5 \%$ \\
\hline \multirow{2}{*}{$\begin{array}{l}\text { Gross } \\
\text { Income } \\
\text { Calculation } \\
\text { Method }\end{array}$} & $\begin{array}{l}\text { Recording (Gross Income }< \\
4.8 \text { Billion Rupiah) }\end{array}$ & $68,3 \%$ & $62,5 \%$ & $67,5 \%$ & $75,0 \%$ \\
\hline & $\begin{array}{l}\text { Bookkeeping (Gross Income } \\
\geq 4.8 \text { Billion Rupiah) }\end{array}$ & $31,7 \%$ & $37,5 \%$ & $32,5 \%$ & $25,0 \%$ \\
\hline \multirow{3}{*}{$\begin{array}{l}\text { Tax Return } \\
\text { Preparation }\end{array}$} & Self-prepared & $45,8 \%$ & $57,5 \%$ & $47,5 \%$ & $32,5 \%$ \\
\hline & Tax Attorney & $49,2 \%$ & $32,5 \%$ & $52,5 \%$ & $62,5 \%$ \\
\hline & Other & $5,0 \%$ & $10,0 \%$ & $0,0 \%$ & $5,0 \%$ \\
\hline
\end{tabular}

Table 3 shows the mean, standard deviation, minimum value and the maximum value of each composite variable which is seen according to each generation group. The mean value of each variable shows the magnitude of each generation's support related to the dependent variable. The higher the mean value, meaning that the generation increasingly supports the dependent variable. Table 3 shows the mean coercive power Baby Boomer of 5.850 followed by Millennials and Generation X with mean 5.025 and 4.913. This shows that Baby Boomers support coercive power more than other generations. Regarding the legitimate power variable, Generation X has the highest mean with 5.321 followed by Millennials who have almost the same mean of 5.221 and Baby Boomers with the lowest mean compared to the other two generations of 3.629. This shows that Generation X and Millennial support more legitimate power than Baby Boomers. In the vertical equity variable, Baby Boomer has the highest mean of 5.592 which is then followed by Millennials with a mean of 4.333 and Generation X with the lowest mean of 3.942. This shows that Baby Boomers support more vertical equity than other generations. In the horizontal equity and Exchange Equity variables, Millennials have the highest mean, followed by Generation X and Baby Boomer. This shows that Millennials are more 
supportive of horizontal equity and exchange equity than other generations. Figure 1 also shows that the graph of Baby Boomers has a different pattern compared to the other graphs.

Table 3. Descriptive Statistics

\begin{tabular}{|c|c|c|c|c|}
\hline $\begin{array}{l}\text { Independent } \\
\text { Variables }\end{array}$ & $\begin{array}{c}\text { Total } \\
\text { Sample }\end{array}$ & Millennials & $\mathrm{X}$ & $\begin{array}{c}\text { Baby } \\
\text { Boomers }\end{array}$ \\
\hline \multicolumn{5}{|c|}{$\mathrm{CP}-$ Composite } \\
\hline Mean & 5,263 & 5,025 & 4,913 & 5,850 \\
\hline SD & 1,438 & 1,489 & 1,643 & 1,182 \\
\hline Minimum & 1,00 & 1 & 1 & 1 \\
\hline Maximum & 7,00 & 7 & 7 & 7 \\
\hline \multicolumn{5}{|c|}{ LP - Composite } \\
\hline Mean & 4,724 & 5,221 & 5,321 & 3,629 \\
\hline $\mathrm{SD}$ & 1,497 & 1,473 & 1,387 & 1,630 \\
\hline Minimum & 1,00 & 1 & 1 & 1 \\
\hline Maximum & 7,00 & 7 & 7 & 7 \\
\hline \multicolumn{5}{|c|}{ VE - Composite } \\
\hline Mean & 4,622 & 4,333 & 3,942 & 5,592 \\
\hline $\mathrm{SD}$ & 1,555 & 1,631 & 1,784 & 1,251 \\
\hline Minimum & 1,00 & 1 & 1 & 1 \\
\hline Maximum & 7,00 & 7 & 7 & 7 \\
\hline \multicolumn{5}{|c|}{ HE - Composite } \\
\hline Mean & 3,775 & 4,350 & 3,742 & 3,233 \\
\hline SD & 1,621 & 1,517 & 1,731 & 1,614 \\
\hline Minimum & 1,00 & 1 & 1 & 1 \\
\hline Maximum & 7,00 & 7 & 7 & 7 \\
\hline \multicolumn{5}{|c|}{ EE - Composite } \\
\hline Mean & 3,750 & 4,108 & 4,250 & 2,892 \\
\hline $\mathrm{SD}$ & 1,511 & 1,491 & 1,715 & 1,327 \\
\hline Minimum & 1,00 & 1 & 1 & 1 \\
\hline Maximum & 7,00 & 7 & 7 & 7 \\
\hline
\end{tabular}

After we tested the coercive power variable, legitimate power, vertical equity, horizontal equity, and exchange equity respectively, according to Table 4 , had significant value 0,$065 ; 0,200 ; 0,065 ; 0,008$; and 0,200 . Only the horizontal equity variable has a significant value below 0.05 . This shows that the horizontal equity variable is not normally distributed. Therefore, we do the Bootstrap. After we tested the coercive power variable, legitimate power, vertical equity, horizontal equity and exchange equity respectively (table 5 ) had a significant value $>0,05$. This shows that all variables used do not occur (homogeneous) heteroscedasticity.

Table 4. Normality Test with Kolmogorov-Smirnov Test

$$
\text { CP - LP - VE - } \text { HE - EE - }
$$

Composite Composite Composite Composite Composite

$\begin{array}{llllll}\text { Sig } & 0,065 & 0,200 & 0,065 & 0,008 & 0,200\end{array}$


Table 5. Heteroscedasticity Test with Levene Test

\begin{tabular}{cccccc}
\hline & $\begin{array}{c}\text { CP - } \\
\text { Composite }\end{array}$ & $\begin{array}{c}\text { LP - } \\
\text { Composite }\end{array}$ & $\begin{array}{c}\text { VE - } \\
\text { Composite }\end{array}$ & $\begin{array}{c}\text { HE - } \\
\text { Composite }\end{array}$ & $\begin{array}{c}\text { EE - } \\
\text { Composite }\end{array}$ \\
\hline F & 0,986 & 0,986 & 1,589 & 1,448 & 1,383 \\
Sig & 0,487 & 0,487 & 0,068 & 0,115 & 0,146 \\
\hline
\end{tabular}

On table 6 , the significance value of generational to coercive power (CP) and legitimate power (LP) show sig value $<0,001$. The result of testing H1 indicates generational effects preference in the application of coercive power of tax officers. A similar result of testing $\mathrm{H} 2$ also indicates generational effects preference in the application of legitimate power in tax collecting. Therefore our hypothesis for $\mathrm{H} 1$ and $\mathrm{H} 2$ are accepted. From table 6, it can be seen that the value of Adjusted R Square for coercive and legitimate power are 0,108 and 0,301 . The results show that the independent variables which are a generational group, gender, business type, and method of calculating income tax can explain the value of coercive and legitimate power of $10,8 \%$ and $30,1 \%$. We also found a significant effect of generational on vertical equity, horizontal equity, and exchange equity. Table 6 shows the significance value of the three variables is below 0,005 . The results confirm that generational affect vertical equity, horizontal equity, and exchange equity. Therefore, H3, H4, and H5 are confirmed.

Table 6. Differential Test Results for ANOVA

\begin{tabular}{lrrrrr}
\hline Independent Variables & $\begin{array}{c}\text { CP - } \\
\text { Composite }\end{array}$ & $\begin{array}{c}\text { LP - } \\
\text { Composite }\end{array}$ & $\begin{array}{c}\text { VE - } \\
\text { Composite }\end{array}$ & $\begin{array}{c}\text { HE - } \\
\text { Composite }\end{array}$ & \multicolumn{1}{c}{$\begin{array}{c}\text { EE - } \\
\text { Composite }\end{array}$} \\
\hline Intercept & & & & & \\
$\quad$ Mean Square & 2816,643 & 2338,471 & 2200,077 & 1494,470 & 1445,564 \\
$F$ & 2290,993 & 1503,238 & 1720,540 & 896,822 & 1177,909 \\
$\quad$ Significance & 0,000 & 0,000 & 0,000 & 0,000 & 0,000 \\
\hline Generational & & & & & \\
$\quad$ Mean Square & 10,236 & 26,680 & 29,733 & 10,930 & 14,663 \\
$F$ & 8,326 & 17,151 & 23,252 & 6,559 & 11,948 \\
$\quad$ Significance & 0,000 & 0,000 & 0,000 & 0,002 & 0,000 \\
\hline Gender & & & & & \\
$\quad$ Mean Square & 0,608 & 11,528 & 0,654 & 0,011 & 19,025 \\
$F$ & 0,495 & 7,411 & 0,511 & 0,007 & 15,502 \\
$\quad$ Significance & 0,483 & 0,008 & 0,476 & 0,934 & 0,000 \\
\hline Business Type & & & & & \\
Mean Square & 1,634 & 1,931 & 0,032 & 0,232 & 7,082 \\
$F$ & 1,329 & 1,241 & 0,025 & 0,139 & 5,771 \\
$\quad$ Significance & 0,251 & 0,268 & 0,874 & 0,710 & 0,018 \\
\hline Income Tax Calculation Method & 0,131 & 3,381 & 0,820 & 2,339 & 0,042 \\
Mean Square & 0,107 & 2,173 & 0,641 & 1,404 & 0,034 \\
$F$ & 0,745 & 0,143 & 0,425 & 0,239 & 0,854 \\
Significance & 0,108 & 0,301 & 0,264 & 0,088 & 0,299 \\
Adjusted R Squared & & & & &
\end{tabular}


The test results of differences perception between generations can be seen in table 7 . Related to coercive power, table 7 shows there are significant differences between Baby Boomers and Millennials $(p=0,001)$ and between Baby Boomers and X $(p=0,000)$, whereas, between Millennial and X, there is no significant difference. The similar result also found concerning legitimate power, shows that there is a significant difference between Baby Boomer and Millennial $(p=0,000)$ and between Baby Boomer and $X(p=0,000)$, whereas, between Millennial and $\mathrm{X}$, there is no significant difference. Regarding vertical equity, shows there is a significant difference between Baby Boomer and Millennial ( $\mathrm{p}=$ $0,000)$ and between Baby Boomer and X $(p=0,000)$, whereas, between Millennial Generation and Generation $\mathrm{X}$, there is no significant difference. Regarding the exchange equity, shows there is a significant difference between Baby Boomer and Millennial $(\mathrm{p}=$ $0,000)$ and between Baby Boomers and X $(p=0,000)$, whereas, between Millennial and X, there is no significant difference $(\mathrm{p}=0,643)$. The different result found regarding horizontal equity shows that there are significant differences between Millennial and X $(p=0,024)$ and between Baby Boomer and Millennial $(p=0,002)$, whereas, between Baby Boomer and Generation $X$, there is no significant difference $(p=0,132)$.

Table 7. Differential Test Results for One Generational Group Towards the Other Group

\begin{tabular}{|c|c|c|c|c|c|c|c|c|c|c|c|}
\hline \multirow[b]{2}{*}{ (I) Gen } & \multirow[b]{2}{*}{ (J) Gen } & \multicolumn{2}{|c|}{ CP - Composite } & \multicolumn{2}{|c|}{ LP - Composite } & \multicolumn{2}{|c|}{ VE - Composite } & \multicolumn{2}{|c|}{ HE - Composite } & \multicolumn{2}{|c|}{$\begin{array}{c}\text { EE - } \\
\text { Composite } \\
\end{array}$} \\
\hline & & $\begin{array}{c}\text { Mean } \\
\text { Diff (I-J) }\end{array}$ & Sig. & $\begin{array}{l}\text { Mean } \\
\text { Diff } \\
\text { (I-J) }\end{array}$ & Sig. & $\begin{array}{c}\text { Mean } \\
\text { Diff } \\
\text { (I-J) }\end{array}$ & Sig. & $\begin{array}{c}\text { Mean } \\
\text { Diff } \\
\text { (I-J) }\end{array}$ & Sig. & $\begin{array}{c}\text { Mean } \\
\text { Diff } \\
\text { (I-J) }\end{array}$ & Sig. \\
\hline BB & Millenn & 0,836 & 0,001 & $-1,409$ & 0,000 & 1,304 & 0,000 & $-1,066$ & 0,002 & $-1,019$ & 0,000 \\
\hline BB & Gen X & 0,958 & 0,000 & $-1,502$ & 0,000 & 1,695 & 0,000 & $-0,474$ & 0,132 & $-1,134$ & 0,000 \\
\hline Millenn & Gen X & 0,122 & 0,624 & $-0,093$ & 0,740 & 0,391 & 0,126 & 0,592 & 0,024 & $-0,115$ & 0,643 \\
\hline
\end{tabular}

We found two groups with different perception regarding the coercive and legitimate power of the DGT. Millennials and X perceive that the application of coercive and legitimate power by the DGT has been implemented in a balanced way. This result can be seen in the average score in Table 8. Millennials give the score of 5,025 and 5,221 for the implementation of coercive and legitimate power. Similarly, with the response of Millennials, generation X give a score of 4,913 and 5,321 for the coercive and legitimate power of tax officers. Different from the Baby Boomers group who perceive that the application of coercive power by the DGT is greater than legitimate power.

Table 8. Mean Score of Coercive and Legitimate Power

\begin{tabular}{l|c|c|c}
\hline \multirow{2}{*}{ Variables } & \multicolumn{3}{|c}{ Mean Score } \\
\cline { 2 - 4 } & Millennials & Gen X & Baby Boomers \\
\hline Coercive Power & 5,025 & 4,913 & 5,850 \\
Legitimate Power & 5,221 & 5,321 & 3,629 \\
\hline
\end{tabular}

From the results of the Millennials and X groups, it can be concluded that they want the application of balanced coercive power and legitimate power because the combination 
of the two produces trust to the DGT as legitimate government institutions to collect taxes (Hofmann et al., 2017). Legitimate power and coercive power in combination might be perceived as legitimate expert power, increase trust by creating the impression that free riders will be penalized while supporting honest taxpayers in order to achieve high-level tax compliance (Hofmann, Gangl, Kirchler, \& Stark, 2014). When looking at Millennials and $\mathrm{X}$ characteristics that are more open, respectful of differences, creative, dislike hierarchy and tradition, exclusive application of coercive power is contrary to the values that they believe in, resulting in a decrease in trust in DGT (Hofmann et al., 2017) and weaken effective social relations and trust each other (Kramer, 1999; Das \& Teng, 2001). Exclusive application of coercive power will also reduce implicit trust, improve antagonistic climate perception, and enforced compliance (Hofmann et al., 2017). Molenmaker, de Kwaadsteniet, \& van Dijk (2014) found that people's willingness to costly reward and punish is not only determined by the type of sanction (reward versus punishment) but is also moderated by the type of social dilemma people face. Taxpayers do not have the option to turn to another tax authority if they are not satisfied with the tax authorities in their country (Hofmann et al., 2017). Therefore in the case of taxpayers and tax authority combination of coercive and legitimate power is essential to build a service climate in order to improve voluntary compliance. Hartl et al. (2015) also found that the combination of applying coercive and legitimate power affected the taxpayer's belief in the power of DGT and increased tax payments. The impact of legitimate power on tax compliance supports the assumption that perceptions of service orientation lead to reciprocal behavior, where taxpayers tend to report their earnings honestly when they believe that the tax authority works for the good of taxpayers (Hartl et al., 2015). With Millennials and X being the most significant tax contributor to the country today, the government should begin to make any adjustments to the services of tax officers and DGT to increase voluntary tax compliance.

Baby Boomers tend to support the implementation of the coercive power concept by the tax authorities. This is also related to the characteristics of the Baby Boomers generation formed by living in wartime. This result supports the previous research of Bencsik and Manova. Baby Boomers are hard workers, profoundly respect tradition and hierarchy, respect for authority figures (Bencsik \& Machova, 2016). The word "respect" for authority figures can often cause fear to make mistakes or break the law.

Regarding tax fairness, we also found that Millennials and $\mathrm{X}$ have a different perception of vertical equity than Baby Boomers. Millennials and X do not support vertical equity. Our result was consistent with one of Jurney et al. (2017). Millennials strongly support the concept of horizontal equity where for the same income will be subject to the same tax burden, regardless of the type of work or business. This has implications for tax regulations that still apply different tax burdens for different business type, including Indonesia. For example tax rules in Indonesia for entrepreneurs with gross income below 4.8 billion, services business or profession are subject to higher tax rates than retail/production businesses. Characteristics of Millennials are having several types of business and not only bound to one job. Millennials desire greater flexibility in working hours (PwC, 2013) and choose freelance or part-time work rather than a typical nine-to-five 
schedule (Taylor, 2017). Simplified calculation and tax rates become important things that need to be considered by the government. In terms of perceptions of exchange equity, Millennials and X have different perceptions than Baby Boomers. Our result confirmed that Millennials and $X$ felt greater exchange equity than Baby Boomers and had a different result with Jurney et al. (2017).

\section{CONCLUSION}

Our result found that Millennials and $\mathrm{X}$ have the perception that tax officers have implemented coercive and legitimate power in a balanced. Different result found in the group of Baby Boomers who assess that tax officers tend to focus on coercive power than legitimate power because Baby Boomers see the application of legitimate power as the application of weak power and are considered less assertive. Differences in the perception indicate that Millennials and X prefer the implication of both powers in continuously and sustainability. With Millennials and $\mathrm{X}$ are the most contributors of tax income in Indonesia, we believe that coercive and legitimate power is essential to build a service climate in order to improve voluntary compliance.

Different test results indicate a significant difference in the perception of each generation regarding vertical equity. Baby Boomer supports the implementation of vertical equity where taxation is imposed progressively, while Millennials and Generation X tend to be less supportive of implementing power with the concept of vertical equity. Regarding horizontal equity, the results of different tests also show significant differences regarding the perception of each generation. Millennials support the application of the concept of horizontal equity. On the other hand, Baby Boomer and Generation X do not support the application of horizontal equity. Regarding the exchange equity, the results of different tests indicate a significant difference in the perception of each generation. Millennials and X felt greater exchange equity than Baby Boomers.

Considering the purpose of this study is to see the differences in intergenerational perceptions related to the authority of tax authorities and tax justice, it can provide an opportunity for subsequent researchers to examine the effect of the application of power by the tax authorities on service-orientation and trust. This research is limited to non-probability sampling. This technique results in non-representative results that cannot be generalized to the population.

\section{REFERENCES}

Andreoni, J., Erard, B., Feinstein, J., Andreoni, J., \& Feinstein, J. (1998). Tax compliance. Journal of Economic Literature, 818-860.

Andringa, T. C., van den Bosch, K. A., \& Vlaskamp, C. (2013). Learning autonomy in two or three steps: linking open-ended development, authority, and agency to motivation. Frontiers in Psychology, 4, 1-18.

Ariel, B. (2012). Deterrence and moral persuasion effects on corporate tax compliance: findings from a randomized controlled trial. Criminology, 50(1), 27-69.

Becker, G. S. (1968). Crime and Punishment : An Economic Approach. Journal of Political Economy, 76, 169-217. 
Bencsik, A., \& Machova, R. (2016). Knowledge sharing problems from the viewpoint of intergeneration management. In Proceeding of 4th International Conference on Management, Leadership, and Governance: ICMLG2016 (p. 42).

Brosdahl, D. J. C., \& Carpenter, J. M. (2011). Shopping orientations of US males: A generational cohort comparison. Journal of Retailing and Consumer Services, 18, 548554. https://doi.org/10.1016/j.jretconser.2011.07.005

Caspi, A., \& Roberts, B. W. (2001). Personality development across the life course: the argument for change and continuity. Psychological Inquiry, 12(2), 49-66.

Darussalam, Kristiaji, B. B., \& Klise, H. (2013). Desain kelembagaaan administrasi perpajakan: perlukah Ditjen Pajak terpisah dari Kementerian Keuangan. Retrieved from

https://www.ortax.org/ortax $/$ mod=issue $\&$ page $=$ show $\& \mathrm{id}=54 \&$ list $=\& \mathrm{q}=\& \mathrm{hlm}=$ 5

Das, T. K., \& Teng, B. (2001). Trust, control, and risk in strategic alliances: an integrated framework. Organization Studies, 22(2), 251-283.

Dencker, J. C., Joshi, A., \& Martocchio, J. J. (2008). Towards a theoretical framework linking generational memories to workplace attitudes and behaviors. Human Resource Management Review, 18(3), 180-187.

Efebera, H., Hayes, D. C., Hunton, J. E., \& O’Neil, C. (2015). Tax compliance intentions of low-income individual taxpayers. Advances in Accounting Behavioral Research, 7, 125.

Gangl, K., Hofmann, E. B., Pollai, M., \& Kirchler, E. (2012). The Dynamics of Power and Trust in the "Slippery Slope Framework" and its Impact on the Tax Climate. Ssrn Electronic Journal, 1-27.

Gangl, K., Hofmann, E., \& Kirchler, E. (2015). Tax authorities' interaction with taxpayers : A conception of compliance in social dilemmas by power and trust. New Ideas in Psychology, 37, 13-23. Retrieved from http://dx.doi.org/10.1016/j.newideapsych.2014.12.001

Gentry, W. A., Griggs, T. L., Deal, J. J., Mondore, S. P., \& Cox, B. D. (2011). A comparison of generational differences in endorsement of leadership practices with actual leadership skill level. Consulting Psychology Journal, 63(1), 39-49. https://doi.org/10.1037/a0023015

Gursoy, D., Maier, T. A., \& Chi, C. G. (2008). Generational differences : An examination of work values and generational gaps in the hospitality workforce, 27, 448-458. https://doi.org/10.1016/j.ijhm.2007.11.002

Hartl, B., Hofmann, E., Gangl, K., Hartner-Tiefenthaler, M., \& Kirchler, E. (2015). Does the sole description of a tax authority affect tax evasion? -The impact of described coercive and legitimate power. PLoS ONE, 10(4), 1-19.

Hartman, J. L., \& Mccambridge, J. (2011). Optimizing Millennials' communication styles. Businees Communication Quarterly, 74(1), 22-44. https://doi.org/10.1177/1080569910395564

Hofmann, E., Gangl, K., Kirchler, E., \& Stark, J. (2014). Enhancing tax compliance through coercive and legitimate power of tax authorities by concurrently diminishing 
or facilitating trust in tax authorities. Law and Policy. https://doi.org/10.1111/lapo.12021

Hofmann, E., Hartl, B., Gangl, K., Hartner-Tiefenthaler, M., \& Kirchler, E. (2017). Authorities' coercive and legitimate power: The impact on cognitions underlying cooperation. Frontiers in Psychology, 8, 1-15.

Jackson, V., Stoel, L., \& Brantley, A. (2011). Mall attributes and shopping value: Differences by gender and generational cohort. Journal of Retailing and Consumer Services, 18, 1-9. https://doi.org/10.1016/j.jretconser.2010.08.002

Jurkiewicz, C. L. (2000). Generation X and the Public Employee. Public Personnel, 29(1), 55-74.

Jurney, S., Rupert, T., \& Wartick, M. (2017). Generational differences in perceptions of tax fairness and attitudes towards compliance. Advances in Taxation, 24, 163-197. https://doi.org/10.1108/S1058-749720170000024004

Kastlunger, B., Lozza, E., Kirchler, E., \& Schabmann, A. (2013). Powerful authorities and trusting citizens : The Slippery Slope Framework and tax compliance in Italy. Journal of Economic Psychology, 34, 36-45. Retrieved from http://dx.doi.org/10.1016/j.joep.2012.11.007

Kirchler, E., Hoelzl, E., \& Wahl, I. (2008). Enforced versus voluntary tax compliance : The "slippery slope" framework. Journal of Economic Psychology, 29, 210-225. https://doi.org/10.1016/j.joep.2007.05.004

Kneeshaw, K., Vaske, J. J., Bright, A. D., \& Absher, J. D. (2004). Acceptability norms toward fire management in three national forests. Environment \& Behavior, 36(4), 592612. https://doi.org/10.1177/0013916503259510

Kock, N., \& Lynn, G. . (2012). Lateral Collinearity and Misleading Results in VarianceBased SEM: An Illustration and Recommendations. Journal of The Association for Information Systems, 13(7), 546-580.

Kramer, R. M. (1999). Trust and distrust in organizations: emerging perspectives, enduring questions. Annual Review Psychology, 50, 569-598.

Lyons, S. (2003). An Exploration of generational values in life and at work (Doctoral thesis). Carleton University, Ottawa, Ontario, Canada.

Misbakhun, H. M. (2018). Reformasi perpajakan untuk meningkatkan kesadaran pajak: disampaikan pada seminar "meningkatkan kesadaran pajak", diselenggarakan oleh Ditjen Pajak Kementerian Keuangan RI, Jakarta.

Molenmaker, W. E., de Kwaadsteniet, E. W., \& van Dijk, E. (2014). On the willingness to costly reward cooperation and punish non-cooperation: The moderating role of type of social dilemma. Organizational Behavior and Human Decision Processes, 125(2), 175183. https://doi.org/10.1016/j.obhdp.2014.09.005

Mulder, L. B., Verboon, P., \& Cremer, D. D. E. (2009). Sanctions and moral judgments : The moderating effect of sanction severity and trust in authorities. European Joumal of Social Psychology, 269(39), 255-269. https://doi.org/10.1002/ejsp

Neal, S., \& Wellins, R. (2018). Generation X not millennials is changing the nature of work. $C N B C$. Retrieved from https://www.cnbc.com/2018/04/11/generation-X--notmillennials--is-changing-the-nature-of-work.html\# 
Noble, S. M., \& Schewe, C. D. (2003). Cohort segmentation : An exploration of its validity. Journal of Business Research, 56, 979-987.

Obal, M., \& Kunz, W. (2013). Trust development in e-services: A cohort analysis of Millennials and Baby Boomers. Journal of Service Management, 24(1), 45-63. https://doi.org/10.1108/09564231311304189

Parry, E., \& Urwin, P. (2011). Generational Differences in Work Values: A Review of Theory and Evidence. International Journal of Management Reviews, 13, 79-96. https://doi.org/10.1111/j.1468-2370.2010.00285.x

PwC. (2013). PwC's NextGen: a global generational study. Retrieved from https://www.pwc.com/gx/en/hr-management-services/pdf/pwc-nextgen-study2013.pdf

Ramli, F., Samdin, Z., Noor, A., Ghani, A., Roslan, M., \& Kasim, M. (2018). Factors affecting users' perception towards conservation of biodiversity in Matang Mangrove Forest Reserve (MMFR), Perak, Malaysia. International Journal of Business and Society, 19(1), 26-36.

Raven, B. H., Schwarzwald, J., \& Koslowsky, M. (1998). Conceptualizing and measuring a power/interaction model of interpersonal influence. Journal of Applied Social Psychology, 28(4), 307-332.

Republic of Indonesia. (2007). Act of The Republic of Indonesia number 28 the year 2007 concerning General Provision and Tax Procedures.

Republic of Indonesia. (2012). Memorandum of Understanding between the Ministry of Finance and the Indonesian National Police MOU-1 / MK.09 / 2012 concerning law enforcement in the field of taxation.

Republic of Indonesia. (2014). Regulation of the Minister of Finance No 111 / PMK.03 / 2014 about Tax Consultant.

Setiaji, H. (2018). Lepas dari Kemenkeu, Saatnya Otoritas Pajak Berdiri Sendiri. CNBC Indonesia. Retrieved from https://www.cnbcindonesia.com/news/20180110135643-4-1113/lepas-darikemenkeu-saatnya-otoritas-pajak-berdiri-sendiri

Siahaan, F. O. P. (2005). The influence of tax fairness, ethical attitudes and commitment on taxpayer compliance behavior. The International Journal of Accounting and Business Society, 13(1), 33-44.

Sittenthaler, S., Steindl, C., \& Jonas, E. (2015). Legitimate vs. illegitimate restrictions â€“ a motivational and physiological approach investigating reactance processes. Frontiers in Psychology, 6, 1-11. https://doi.org/10.3389/fpsyg.2015.00632

Taylor, T. . (2017). Workplace Flexibility For Millennials: Appealing To A Valuable New Generation. Retrieved from https://www.forbes.com/sites/adp/2017/12/07/workplace-flexibility-formillennials-appealing-to-a-valuable-new-generation/\#453b7c937fe6

Tjondro, E., Santosa, K. G., \& Prayitno, N. (2019). Perceptions of service-orientation and trust of tax officers between millennials, $\mathrm{x}$, and baby boomers. MIX: Jurnal Ilmiah Manajemen, 9(1), 1-18. 


\section{Appendix}

\begin{tabular}{|c|c|}
\hline & Survey Questions \\
\hline CP1 & believe the Director General of Taxes gives strict sanctions for tax evaders. \\
\hline CP2 & I believe the Director General of Taxes enforce their goals through audits and sanctions. \\
\hline CP3 & I believe the Director General of Taxes give strict sanctions when taxpayers make mistakes. \\
\hline CP4 & $\begin{array}{l}\text { I believe the Director General of Taxes conducts audits and provides penalties to taxpayers } \\
\text { forcibly. }\end{array}$ \\
\hline LP1 & I believe the Director General of Taxes understands how to provide useful advice to taxpayers. \\
\hline LP2 & I believe the Director General of Taxes provides professional advice to taxpayers. \\
\hline LP3 & I believe the Director General of Taxation is a partner to settle tax obligations of taxpayers. \\
\hline LP4 & I appreciate the Director General of Taxes for providing useful information and advice. \\
\hline LP5 & I believe the Director General of Taxes is obliged to collect taxes legitimately. \\
\hline LP6 & I respect the Director General of Taxes for the high standards of work and services they applied. \\
\hline LP7 & $\begin{array}{l}\text { I respect the Director General of Taxes because they provide useful information for taxpayers } \\
\text { in carrying out obligations appropriately. }\end{array}$ \\
\hline VE1 & $\begin{array}{l}\text { The income tax that I paid was fair compared to other income tax that had a higher income } \\
\text { than me. }\end{array}$ \\
\hline VE2 & I pay a higher income tax than taxpayers who have higher economic capabilities. \\
\hline VE3 & Taxpayers who have higher economic capacity pay greater income tax than me. \\
\hline HE1 & I pay income tax almost as much as other people who earned the same income. \\
\hline HE2 & Most people who earn the same income pay higher income tax than me. \\
\hline HE3 & I pay a higher income tax compared to most people who earn the same income. \\
\hline EE1 & $\begin{array}{l}\text { The income tax I paid was equal to the benefits that I received in the form of government } \\
\text { facilities and services. }\end{array}$ \\
\hline EE2 & The income tax that I paid was greater than the services that I received from the government. \\
\hline EE3 & $\begin{array}{l}\text { I am satisfied with the benefits I receive from the government compared to the amount of } \\
\text { income tax that I pay. }\end{array}$ \\
\hline
\end{tabular}

